\title{
HUBUNGAN ANTARA KARAKTERISTIK SENSORIK MAKANAN DENGAN SISA MAKANAN BIASA PADA PASIEN RAWAT INAP RSUD DR. SOERATNO, GEMOLONG, KABUPATEN SRAGEN
}

\author{
Vivin Ariyanti $^{1}$, Endang Nur Widyaningsih ${ }^{2}$, Rusdin Rauf ${ }^{3}$ \\ ${ }^{1}$ RSUD dr Soeratno Gemolong Jl. Dr Soetomo No. 792, Gemolong, Kabupaten Sragen, \\ Jawa Tengah. Email: ${ }^{1}$ vivinariyanti82@ rocketmail.com \\ ${ }^{2,3}$ Program Studi Ilmu Gizi Fakultas Ilmu Kesehatan Universitas Muhammadiyah \\ Surakarta. Jl. A. Yani, Pabelan, Kartasura, Surakarta. Email: ${ }^{2}$ en239@ums.ac.id, \\ 3rusdin.rauf@ums.ac.id
}

\begin{abstract}
ABSTRAK
Makanan yang disajikan di rumah sakit berfungsi untuk mempertahankan daya tahan tubuh dan membantu proses penyembuhan sehingga tingginya sisa makanan dapat berpengaruh terhadap kesehatan pasien. Tujuan penelitian untuk mengetahui hubungan antara karakteristik sensorikmakanan dengan sisa makanan biasa pada pasien rawat inap RSUD dr. Soeratno Gemolong. Jenis penelitian ini adalah crossectional. Jumlah responden 40orang, dipilih dengan cara konsekutif sampling. Data yang dikumpulkan meliputi karakteristik sensorik makanan yaitu warna, aroma, rasa dan tekstur makanan yang diperoleh melalui kuesioner makan pagi, siang dan sore serta data sisa makanan pasien yang diperoleh dengan metode penimbangan. Data dianalisis dengan uji korelasi Pearson Product Moment. Secara keseluruhan karakteristik sensorik makanan (warna, aroma, rasa,tekstur) dalam kategori Baik. Karakeristik sensorik pada warna kategori menarik 87,5\%, pada aroma kategori sedap 82,5\%, pada rasa kategori enak $85,5 \%$ dan pada tekstur kategori sesuai $97,5 \%$. Rata-rata sisa makanan responden $26,6 \%$. Secara statistik, ada hubungan antara warna, aroma dan rasa makanan dengan sisamakanan biasa pada pasien rawat inap di RSUD dr. Soeratno Gemolong. Tidak ada hubungan antara tekstur makanan dengan sisa makanan biasa pada pasien rawat inap RSUD dr. Soeratno Gemolong.
\end{abstract}

Kata kunci: Karakteristik sensorik makanan, sisa makanan

\begin{abstract}
Food served in the hospital plays a role to maintain endurance and help to heal so that the presence of food waste can affect the health of patients. The objective of the study was to find out the relationship between food sensory characteristics with ordinary food waste in inpatients of RSUD dr. Soeratno Gemolong. The type of the research was crossectional. The number of respondents was 40 people, selected by consecutive sampling. The data collected were food sensory characteristics including the color, aroma, taste, and texture of the food obtained through the morning, afternoon and afternoon food questionnaires. The food waste of respondents was obtained by
\end{abstract}


weighing. Data were analyzed using Pearson Product Moment correlation test. Overall food sensory characteristics (color, aroma, taste, texture) indicated the Good category. The color of food gave attracted category, was $87.5 \%$. The aroma of food displayed the savory, was $82.5 \%$. The food taste revealed the tasty category, was $85.5 \%$. The food texture indicated the right category, was $97.5 \%$. The average food residue of respondents was $26.6 \%$. Statistically, there was a relationship between color, aroma, and taste of food with ordinary food remnants in hospitalized patients in dr. Soeratno Gemolong. However, there was no correlation between food texture with ordinary food remnants in hospitalized dr. Soeratno Gemolong.

Keywords: Sensory characteristics of food, food waste

\section{PENDAHULUAN}

Standar akreditasi rumah sakit menyebutkan bahwa pelayanan gizi tidak hanyapenyediaan makanan bagi pasien dan petugas saja tetapi yang terpenting adalah penyediaan makanan yang memenuhi kebutuhan metabolisme manusia untuk pemulihan dan mengoreksi kelainan metabolisme (Depkes, 2011). Kepuasan pasien terhadap pelayanan gizi di rumah sakit mempengaruhi asupan makan pasien selama dirawat. Faktorfaktor yang mempengaruhi kepuasan pasien di rumah sakit diantaranya variasi menu, cara penyajian makanan, ketepatan waktu menghidangkan makanan, keadaan tempat waktu makan, kebersihan makanan yang dihidangkan serta sikap dan perilaku petugas yang menghidangkan makanan (Suryawati dkk., 2006). Makanan yang disajikan di rumah sakit berfungsi untuk mempertahankan daya tahan tubuh dan membantu proses penyembuhan sehingga makanan yang disajikan harus memenuhi kebutuhan baik kualitas, kuantitas, kecukupan akan gizi maupun ketepatan dietnya (Almatsier, 2006).

Masalah pelayanan gizi di rumah sakit yang sering terjadi adalah banyaknya sisa makanan pasien rawat inap itu berarti tujuan pelayanan gizi kurang tepat. Oleh karena itu diperlukan pengukuran atas sisa makan yang disajikan tersebut.
Pengukuran sisa makan berfungsi untuk mengetahui daya terima pasien terhadap makanan yang disajikan. Hal ini berarti analisa sisa makanan merupakan suatu cara untuk melakukan evaluasi terhadap pelayanan gizi yang telah diberikan terutama pelayanan makanan (Depkes, 2011). RSUD dr. Soeratno Gemolong adalah salah satu rumah sakit tipe D yang memberikan pelayanan kesehatan bagi masyarakat umum. RSUD dr. Soeratno Gemolong menggunakan siklus menu 10 hari dengan penambahan menu ke 11 untuk tanggal 31. Harapan rencana preskripsi diet yang dikelola dengan baik di RSUD dr. Soeratno Gemolong belum optimal, berdasarkan survei pendahuluan pada 30 pasien kelas III diketahui sisa makanan pasien sebesar $72 \%$ pada makanan pokok, $28 \%$ pada lauk hewani, $70 \%$ pada lauk nabati dan $65 \%$ pada sayuran. Hasil tersebut menunjukkan masih terdapat sisa makanan yang cukup tinggi, berarti tujuan pelayanan gizi di RSUD dr. Soeratno Gemolong belum tepat sasaran. Berdasarkan latar belakang tersebut, maka perlu dilakukan penelitian tentang hubungan antara karakteristik sensorik makanan dengan sisa makanan biasa pada pasien rawat inap di RSUD dr. Soeratno Gemolong, Kabupaten Sragen. 


\section{METODE PENELITIAN}

Penelitian ini menggunakan rancangan cross sectional dengan subjek penelitian adalah pasien rawat inap pada ruang VIP, kelas 1, kelas 2 dan kelas 3 di RSUD dr. Soeratno Gemolong pada bulan Agustus 2015. Teknik pengambilan sampel dengan cara konsekutif sampling dimana mencari responden yang memenuhi kriteria inklusi dan eksklusi sampai terpenuhi jumlah sampel yang diperlukan. Kriteria inklusi yaitu seluruh pasien yang menjalani rawat inap, telah dirawat minimal 2 hari, bersedia menjadi responden, usia $\geq 15$ tahun, dapat diajak berkomunikasi secara verbal, pasien mendapat makanan biasa dan tidak sedang menjalani diet khusus. Kriteria eksklusi diantaranya pasien pulang atas permintaan sendiri, pasien tidak mau makan makanan yang disajikan rumah sakit dan pasien anoreksia. Jumlah sampel penelitian ini sebanyak 40 responden.

Penelitian dilaksanakan setelah proses perijinan selesai, kemudian mempersiapkan instrument berupa kuesioner karakteristik sensorik makanan dan form sisa makan pasien. Penelitian dibantu ahli gizi RSUD dr. Soeratno Gemolong.

Pengumpulan data penelitian meliputi data tentang karakteristik sensorik makanan (warna, aroma, rasa, dan tekstur) dan data sisa makanan pasien yang didapatkan dengan cara penimbangan. Kemudian data dianalisis dengan program SPSS 21 kemudian data di uji menggunakan uji Pearson Product Moment.

\section{HASIL DAN PEMBAHASAN}

\section{Karakteristik Responden}

Karakteristik responden dalam penelitian ini meliputi tingkat pendidikan, jenis kelamin dan jenis pekerjaan.Tingkat pendidikan yaitu pendidikan terakhir yang dapat diselesaikan responden. Tingkat pendidikan responden dibagi menjadi 2 kriteria yakni pendidikan dasar dan pendidikan lanjut. Deskripsi mengenai karakteristik responden dapat dilihat seperti pada Tabel 1.

Tabel 1. Karakteristik Responden berdasarkan tingkat pendidikan, jenis kelamin dan pekerjaan

\begin{tabular}{|c|c|c|}
\hline Variabel & $\mathbf{n}$ & $\%$ \\
\hline \multicolumn{3}{|l|}{ a. Tingkat Pendidikan } \\
\hline Dasar (SD, SMP) & 32 & 80 \\
\hline Lanjut (SMA, PT) & 8 & 20 \\
\hline \multicolumn{3}{|l|}{ b. Jenis Kelamin } \\
\hline Laki-laki & 20 & 50 \\
\hline Perempuan & 20 & 50 \\
\hline \multicolumn{3}{|l|}{ c. Pekerjaan } \\
\hline PNS & 4 & 10 \\
\hline Buruh tani & 20 & 50 \\
\hline Buruh pabrik & 16 & 40 \\
\hline
\end{tabular}

Berdasarkan Tabel 1 tingkat pendidikan responden sebagian besar berpendidikan dasar yaitu 32 orang $(80 \%)$. Pendidikan menurut Notoadmojo (2010) merupakan suatu proses pembelajaran atau kegiatan untuk mengembangkan dan meningkatkan kemampuan tertentu sehingga sasaran atau tujuan pendidikan akan tercapai. Tingkat pendidikan juga mempengaruhi pandangan dan kebiasaan orang dalam menilai dan memahami zat gizi bagi tubuh. Jumlah responden pasien rawat inap RSUD dr. Soeratno Gemolong, Kabupaten Sragen sama antara laki-laki dan perempuan yaitu masing-masing $50,0 \%$. Sebagian besar pasien rawat inap RSUD dr. Soeratno Gemolong, Kabupaten Sragen bekerja sebagai buruh tani yaitu $50 \%$ hal ini mungkin dikarenakan lingkungan sekitar RSUD dr. Soeratno adalah lahan pertanian dan tingkat pendidikan yang masih banyak pada tingkat dasar.

\section{Penilaian karakteristik sensorik makanan}

Penilaian sensorik makanan adalah penggunaan satu atau lebih alat indera 
manusia untuk menilai atau membuat opini pada beberapa aspek pada mutu makanan (Hubeis dan Kadarisman, 2007. Berikut tabel penilaian karakteristik sensorik makanan yang di sajikan di RSUD dr. Soeratno Gemolong.

\section{a. Penilaian Karakteristik Sensorik Makanan}

Penilaian karakteristik sensorik makanan meliputi warna, aroma, rasa dan tekstur dapat dilihat pada Tabel 2.

Tabel 2. Distribusi Penilaian Karakteristik Sensorik Makanan

\begin{tabular}{|c|c|c|c|c|c|c|}
\hline \multirow{3}{*}{$\begin{array}{c}\text { Karakteristik } \\
\text { sensorik }\end{array}$} & \multicolumn{4}{|c|}{ Kategori } & \multirow{2}{*}{\multicolumn{2}{|c|}{ Total }} \\
\hline & \multicolumn{2}{|c|}{1} & \multicolumn{2}{|c|}{2} & & \\
\hline & $\mathbf{N}$ & $\%$ & $\mathbf{N}$ & $\%$ & $\mathbf{N}$ & $\%$ \\
\hline Warna & 5 & 12,5 & 35 & 87,5 & 40 & 100 \\
\hline Aroma & 7 & 17,5 & 33 & 82,5 & 40 & 100 \\
\hline Rasa & 6 & 15,0 & 34 & 85,0 & 40 & 100 \\
\hline Tekstur & 1 & 2,5 & 39 & 97,5 & 40 & 100 \\
\hline
\end{tabular}

Keterangan:

Katagori 1 : tidak menarik/ tidak sedap/ tidak enak/tidak sesuai

Katagori 2 : menarik/ sedap/ enak/ sesuai
Pada Tabel 2 diketahui bahwa sebagian besar responden menilai karakteristik sensorik makanan pada warna menilai menarik $87,5 \%$, aroma menilai sedap $82,5 \%$, rasa menilai enak $85 \%$ dan tekstur menialai sesuai 97,5\%.Sehingga dapat disimpulkan bahwa sebaian besar responden dapat menerima karakteristik sensorik makanan yang disajikan dengan baik.Penilaian sensorik bersifat subjektif pada masing-masing responden. Faktor kesukaan dan kebiasaan makan sebelum masuk rumah sakit juga berpengaruh terhadap penilaian responden.

\section{b. Penilaian Karakteristik Sensorik Makanan Menurut Jenis Makanan \\ Penilaian karakteristik sensorik} makanan menurut jenis makanan dilakukan dengan menganalisa penilaian responden terhadap karakteristik makanan pada tiap jenis makanan yang meliputi makanan pokok, lauk hewani, lauk nabati dan sayur. Berikut Tabel 3 distribusi penilaian karakteristik sensorik makanan menurut jenis makanan.

Tabel 3. Distribusi Penilaian Karakteristik Sensorik Makanan menurut Jenis Makanan

\begin{tabular}{|c|c|c|c|c|c|c|c|}
\hline \multirow{3}{*}{ Penilaian } & \multirow{3}{*}{ Jenis makanan } & \multicolumn{4}{|c|}{ Kategori } & \multirow{2}{*}{\multicolumn{2}{|c|}{ Total }} \\
\hline & & \multicolumn{2}{|c|}{1} & \multicolumn{2}{|c|}{2} & & \\
\hline & & $\mathbf{N}$ & $\%$ & $\mathbf{N}$ & $\%$ & $\mathbf{N}$ & $\%$ \\
\hline \multirow[t]{5}{*}{ Warna } & Makanan pokok & 33 & 82,5 & 7 & 17,5 & 40 & 100 \\
\hline & Lauk hewani & 30 & 75,0 & 10 & 25,0 & 40 & 100 \\
\hline & Lauk nabati & 28 & 70,0 & 12 & 30,0 & 40 & 100 \\
\hline & Sayur & 30 & 75,0 & 10 & 25,0 & 40 & 100 \\
\hline & Rata-rata & & 75,6 & & 24,4 & & \\
\hline \multirow[t]{5}{*}{ Aroma } & Makanan pokok & 24 & 60,0 & 16 & 40,0 & 40 & 100 \\
\hline & Lauk hewani & 23 & 57,5 & 17 & 42,5 & 40 & 100 \\
\hline & Lauk nabati & 21 & 52,5 & 19 & 47,5 & 40 & 100 \\
\hline & Sayur & 32 & 80,0 & 8 & 20,0 & 40 & 100 \\
\hline & Rata-rata & & 62,5 & & 37,5 & & \\
\hline \multirow[t]{5}{*}{ Rasa } & Makanan pokok & 30 & 75,0 & 10 & 25,0 & 40 & 100 \\
\hline & Lauk hewani & 33 & 82,5 & 7 & 17,5 & 40 & 100 \\
\hline & Lauk nabati & 23 & 57,5 & 17 & 42,5 & 40 & 100 \\
\hline & Sayur & 25 & 62,5 & 15 & 37,5 & 40 & 100 \\
\hline & Rata-rata & & 69,4 & & 30,6 & & \\
\hline \multirow[t]{5}{*}{ Tekstur } & Makanan pokok & 36 & 90,0 & 14 & 10,0 & 40 & 100 \\
\hline & Lauk hewani & 38 & 95,0 & 2 & 5,0 & 40 & 100 \\
\hline & Lauk nabati & 34 & 84,2 & 19 & 15,8 & 40 & 100 \\
\hline & Sayur & 36 & 90,0 & 4 & 10,0 & 40 & 100 \\
\hline & Rata-rata & & 89,8 & & 10,2 & & \\
\hline
\end{tabular}

Keterangan:

a. Katagori 1 : menarik/ sedap/ enak/ sesuai

b. Katagori 2 : tidak menarik/ tidak sedap/ tidak enak/tidak sesuai. 
Pada Tabel 3 dapat diketahui bahwa sebagian besar responden yaitu $>60 \%$ menilai warna makanan menarik, aroma sedap, rasa enak dan tekstur sesuai, hal ini berarti penilaian responden terhadap keseluruhan karakteristik sensorik makanan yang disajikan sebagian besar menilai baik. Dilihat dari jenis makanan yang disajikan, responden yang menyatakan karakteristik sensorik katagori 2 (tidak menarik, tidak sedap tidak enak dan tidak sesuai) dengan jumlah terbanyak yaitu pada jenis makanan lauk nabati. Berdasar hasil wawancara sebagian besar responden menilai lauk nabati yang disajikan di RSUD dr. Soeratno Gemolong kurang bervariasi dari segi jenis dan cara memasaknya yakni hanya terbatas pada jenis tahu atau tempe. Cara memasak lauk nabati juga hanya terbatas pada bacem dan bumbu kuning. Hal ini merupakan salah satu faktor kurangnya penilaian responden terhadap lauk nabati yang disajikan.

\section{Sisa Makanan Biasa}

Sisa makanan dikatagorikan menjadi dua yaitu sedikit bila sisa makanan $\leq 20 \%$ dan sisa banyak bila sisa makanan $>20 \%$. Katagori sisa makanan responden dapat dilihat pada Tabel 4.

Tabel 4. Distribusi Katagori Sisa Makanan

\begin{tabular}{ccc}
\multicolumn{3}{c}{ Biasa } \\
\hline Kategori sisa & \multicolumn{2}{c}{ Frekuensi } \\
\cline { 2 - 3 } makanan & $\mathbf{N}$ & $\%$ \\
\hline Sedikit & 26 & 65 \\
Banyak & 14 & 35 \\
Total & 40 & 100 \\
\hline
\end{tabular}

Tabel 4 menunjukkan bahwa sebagian besar responden memiliki sisa makanan dalam katagori sedikit namun tidak sedikit pula responden yang memiliki sisa makanan dalam kategori banyak. Dari 40 responden yang ditimbang makanannya diproleh 26 responden $(65 \%)$ yang memiliki sisa makanan kategori sedikit yakni $\leq 20 \%$, sedangkan 14 responden (35\%) memiliki sisa makanan dalam kategori banyak.

Secara total rata-rata sisa makanan pasien adalah 26,6\%, angka tersebut diatas Standar Pelayanan Minimal (SPM) rumah sakit menurut Depkes (2011) yaitu sisa makan maksimal $20 \%$ dari total makanan yang disajikan. Berdasarkan hasil penelitian ini dapat diketahui bahwa sisa makanan pasien di RSUD dr. Soeratno Gemolong masih cukup tinggi. Hasil ini jika dibandingkan dengan penelitian Munawar (2011) di RSUP Hasan Sadikin Bandung masih lebih rendah yaitu sisa makanan lunak pasien juga diatas SPM yakni sebesar 31,20\%. Berikut hasil sisa makanan responden menurut jenis makanan dan waktu makan.

\section{1) Sisa makanan menurut jenis makanan}

Sisa makanan ditimbang pada setiap jenis makanan meliputi makanan pokok, lauk hewani, lauk nabati dan sayur kemudian disajikan dalam bentuk persentase. Berikut rata-rata sisa makanan pasien berdasarkan jenis makanan yang disajikan.

Tabel 5. Rata- rata Sisa Makanan Pasien Berdasarkan Jenis Makanan

\begin{tabular}{lc}
\hline Jenis makanan & $\begin{array}{c}\text { Rata-rata sisa } \\
\text { makanan }(\%)\end{array}$ \\
\hline Makanan pokok & $18,9 \%$ \\
Lauk hewani & $9,5 \%$ \\
Lauk nabati & $30,0 \%$ \\
Sayur & $48,0 \%$ \\
Total rata-rata & $26,6 \%$ \\
\hline
\end{tabular}

Tabel 5 menunjukkan bahwa sisa makanan pokok dan lauk hewani masuk dalam kategori sedikit sedangkan sisa lauk nabati dan sayur masuk dalam kategori banyak. Sisa makanan paling banyak terdapat pada sisa sayur yakni $48 \%$. Penelitian ini serupa dengan penelitian Nida (2012) di RSJ Sambang Lihum dimana sayur juga merupakan sisa makanan paling banyak yaitu $67,8 \%$. 
Hasil dari penilaian responden menyatakan bahwa cara memasak sayuran kurang bervariasi dan ada beberapa responden yang kurang menyukai sayuran karena kebiasaan di rumah yang tidak pernah makan sayuran. Hal ini sesuai dengan pendapat Moehyi (2004) bahwa ketidakpuasan pasien terhadap makanan yang diberikan akan dipengaruhi oleh kebiasaan dan pola makan pasien di rumah sebelum masuk rumah sakit.

\section{2) Sisa makanan menurut waktu makan}

Sisa makanan responden dilakukan penimbangan pada setiap waktu makan yaitu pada makan pagi, makan siang dan makan sore. Hasil penimbangan dibagi dalam 2 kriteria yaitu sisa sedikit jika sisa makanan < 20\% dan sisa banyak jika sisa makanan $>20 \%$. Distribusi sisa makanan menurut waktu makan disajikan pada Tabel 6.
Tabel 6. Distribusi Sisa Makanan Biasa Menurut Waktu Makan

\begin{tabular}{lcccccc}
\hline \multirow{2}{*}{$\begin{array}{l}\text { Waktu } \\
\text { makan }\end{array}$} & \multicolumn{4}{c}{ Sisa makanan } & \multicolumn{2}{c}{ Total } \\
\cline { 2 - 5 } & \multicolumn{2}{c}{ Banyak } & \multicolumn{2}{c}{ Sedikit } & \multicolumn{2}{c}{} \\
\cline { 2 - 6 } & $\mathbf{N}$ & $\boldsymbol{\%}$ & $\mathbf{N}$ & $\mathbf{\%}$ & $\mathbf{N}$ & $\boldsymbol{\%}$ \\
\hline Pagi & 17 & 42,5 & 23 & 57,5 & 40 & 100 \\
Siang & 12 & 30,0 & 28 & 70,0 & 40 & 100 \\
Sore & 14 & 35,0 & 26 & 65,0 & 40 & 100 \\
Total & 49 & 40,8 & 71 & 59,2 & 120 & 100 \\
\hline
\end{tabular}

Menurut waktu makan pada Tabel 6 hasil yang diperoleh untuk makan pagi menyisakan makanan dalam katagori sedikit paling rendah bila dibandingkan sisa makanan pada waktu siang dan sore. Salah satu penyebabnya adalah beberapa responden telah mengkonsumsi makanan dari luar rumah sakit sehingga makanan dari rumah sakit tidak dapat dihabiskan.

\section{Hubungan antara karakteristik sensorik makanan dengan sisa makanan.}

Uji hubungan antara karakteristik sensorik makanan pada warna, aroma, rasa dan tekstur dengan sisa makanan biasa terlihat pada Tabel 7 .

Tabel 7. Hubungan antara Karakteristik Sensorik Makanan dengan Sisa Makanan Biasa

\begin{tabular}{llllll}
\hline $\begin{array}{c}\text { Karakteristik Sensorik } \\
\text { Makanan }\end{array}$ & $\begin{array}{c}\text { Sisa } \\
\text { Makanan } \\
\text { Pokok }\end{array}$ & $\begin{array}{c}\text { Sisa } \\
\text { Lauk } \\
\text { Hewani }\end{array}$ & $\begin{array}{c}\text { Sisa } \\
\text { Lauk } \\
\text { Nabati }\end{array}$ & $\begin{array}{c}\text { Sisa } \\
\text { Sayur }\end{array}$ & $\begin{array}{c}\text { Sisa Makanan } \\
\text { Keseluruhan }\end{array}$ \\
\hline a. Warna & & & & & \\
$\quad$ Pearson & .126 & .061 & -.266 & -.159 & -.357 \\
$\quad$ Correlation & .439 & .711 & .097 & .328 & .024 \\
$\quad \begin{array}{l}\text { Sig. (2-Tailed) } \\
\text { b. Aroma }\end{array}$ & & & & & \\
$\quad$ Pearson & -.066 & -.348 & -.377 & -.193 & -.490 \\
$\quad$ Correlation & .687 & .028 & .017 & .232 & .001 \\
$\quad$ Sig. (2-Tailed) & & & & & \\
c. Rasa & & & & & \\
$\quad$ Pearson & -.093 & -.381 & -.176 & -.193 & -.279 \\
$\quad \begin{array}{l}\text { Correlation } \\
\quad \text { Sig. (2-Tailed) }\end{array}$ & .567 & .015 & .256 & .276 & .081 \\
d. Tesktur & & & & & \\
$\quad$ Pearson & & & & & \\
$\quad$ Correlation & .053 & .026 & -.177 & -.067 & -.218 \\
$\quad$ Sig. (2-Tailed) & .744 & .875 & .274 & .680 & .176 \\
\hline
\end{tabular}

Hasil analisis hubungan antara warna makanan dengan sisa makanan biasa diperoleh bahwa pada setiap jenis makanan tidak terdapat hubungan yang signifikan yakni hasil uji statistik diperoleh bahwa nilai sig $>0.05$. 
Hasil pada sisa makanan secara keseluruhan didapatkan nilai yang berbeda yakni nilai sig <0.05 yang artinya terdapat hubungan antara warna makanan dengan sisa makanan. Hasil korelasi pearson bertanda negatif ini artinya adanya arah yang berlawanan antara kedua variabel dimana semakin tinggi hasil penjumlahan skor penilaian responden terhadap warna makanan maka sisa makanan yang diperoleh semakin sedikit Hasil penelitian tersebut serupa dengan penelitian Munawar (2011) di RSHS Bandung yang menyatakan bahwa responden yang beranggapan warna makanan tidak menarik akan menyisakan makanan lebih banyak sedangkan responden yang menyatakan warna makanan menarik akan menyisakan makanan lebih sedikit.

Hasil analisis hubungan pada aroma diperoleh yaitu terdapat hubungan antara aroma makanan dengan sisa makanan pada jenis lauk hewani dan lauk nabati yakni diperoleh nilai sig <0.05. Hasil koefisien korelasi bertanda negatif berarti adanya arah yang berlawanan pada kedua variabel. Dapat disimpulkan bahwa responden yang menilai bahwa aroma makanan tergolong sedap akan menyisakan makanan tergolong sedikit. Hasil uji statistik secara keseluruhan diperoleh bahwa nilai Sig $<0.05$ maka terdapat hubungan antara aroma makanan dengan sisa makanan. Hasil penelitian ini berbeda dengan penelitian yang dilakukan Uyami dkk. (2012) yang menjelaskan bahwa hasil perbedaan daya terima berdasarkan variabel aroma, rasa, suhu, kematangan, warna, variasi dan porsi pada kelompok menu pilihan dan menu standar didapatkan hasil bahwa hanya pada variasi makanan yang memiliki perbedaan daya terima.

Hasil analisis hubungan antara rasa makanan dengan sisa makanan biasa diperoleh adanya hubungan yang bermakna hanya pada sisa lauk hewani namun hasil uji statistik pada warna dengan sisa makanan secara keseluruhan diperoleh bahwa nilai sig $<0.05$ yang artinya terdapat hubungan antara rasa makanan dengan sisa makanan. Penelitian ini sejalan dengan penelitian Khairunnas (2007) dimana terdapat hubungan yang bermakna antara rasa makanan dengan sisa makanan.

Hasil analisis hubungan antara tekstur makanan dengan sisa makanan biasa diperoleh hasil uji statistik dengan nilai sig >0.05 maka dapat disimpulkan tidak terdapat hubungan antara tekstur makanan dengan sisa makanan baik pada sisa setiap jenis makanan maupun pada sisa makanan secara keseluruhan. Penelitian ini sesuai dengan penelitian Rijadi (2002) tentang faktor-faktor yang berhubungan dengan terjadinya sisa makanan pasien rawat inap di RSI Samarinda yakni tidak terdapat hubungan antara tekstur makanan dengan terjadinya sisa makanan pada pasien.

\section{Karakteristik sensorik makanan secara keseluruhan}

Karakteristik sensorik makanan secara keseluruhan meliputi warna, aroma, rasa dan tekstur makanan pada pasien rawat inap yang disajikan di RSUD dr. Soeratno Gemolong. Berdasarkan perhitungan dengan metode skor (Riduwan, 2009).

Diperoleh hasil berdasarkan perhitungan tersebut yakni $75 \%$ sehingga masuk dalam nilai antara $61 \%-80 \%$ yang berarti dalam katagori baik. Dapat disimpulkan bahwa karakteristik sensorik makanan yang disajikan kepada pasien rawat inap RSUD dr. Soeratno Gemolong secara keseluruhan (warna, aroma, rasa dan tekstur) termasuk dalam katagori baik. Karakteristik sensorik makanan adalah ciri makanan yang dimunculkan oleh satu atau kombinasi dari dua atau lebih sifat-sifat yang dapat dikenali dengan menggunakan panca indera manusia (Hubeis dan Kadarisman, 2007). Ini berarti kombinasi 
dari warna, aroma, rasa dan tekstur yang dihasilkan oleh makanan yang disajikan pada pasien rawat inap di RSUD $\mathrm{dr}$. Soeratno Gemolong dalam katagori baik.

\section{KESIMPULAN}

Karakteristik sensorik makanan secara keseluruhan (warna, aroma, rasa dan tekstur) yang disajikan di RSUD dr Soeratno Gemolong masuk dalam kategori baik yakni pada warna kategori menarik $87,5 \%$, aroma kategori sedap $82,5 \%$, rasa kategori enak $85,5 \%$ dan tekstur kategori sesuai $97,5 \%$. Hasil sisa makanan biasa pada pasien rawat inap RSUD $d r$. Soeratno Gemolong kategori sedikit sebanyak 26 responden $(65 \%)$ dan kategori banyak 14 responden (35\%) dengan rata-rata sisa makan pasien RSUD dr. Soeratno Gemolong adalah 26,6\%. Hasil analisis hubungan pada penelitian ini yaitu terdapat hubungan antara warna, aroma dan rasa makanan dengan sisa makanan biasa pada pasien rawat inap namun tidak terdapat hubungan antara tekstur makanan dengan sisa makanan biasa pada pasien rawat inap di RSUD dr. Soeratno Gemolong.

\section{DAFTAR PUSTAKA}

Almatsier, S., 2006, Penuntun Diet, Gramedia Pustaka Umum, Jakarta.

Depkes RI., 2011, Pedoman Pelayanan Gizi Rumah Sakit, Direktorat Rumah Sakit Khusus dan Swasta, Dit. Jen.Yanmedik, Jakarta

Hubeis, M., dan Kadarisman, D., 2007, Pengendalian Mutu Pada Industri Pangan. Universitas Terbuka, Jakarta.

Khairunnas., 2007, Faktor-faktor yang Mempengaruhi Terjadinya Sisa Makanan pada Pasien yang dirawat Inap di Rumah Sakit DR. Achmad Mochtar Bukit Tinggi, Tesis, FKM UGM, Yogyakarta.

Moehyi, S., 2004, Penyelenggaran Makanan Institusi dan Jasa Boga, Bhatara, Jakarta.

Munawar, Asep A., 2011,Hubungan Penampilan Makanan, Rasa Makanan dan Faktor Lainnya dengan Sisa makanan Pasien Kelas 3 di RSUP dr. Hasan Sadikin Bandung, Tesis, FKM UI.

Nida, K., 2012, Faktor-faktor yang Berhubungan dengan Sisa Makanan Pasien Rawat Inap di RSJ Sambang Lihum, Skripsi, Sekolah Tinggi Ilmu Kesehatan Husada Borneo Banjar Baru.

Notoatmodjo, S.,2010, Metodologi Penelitian Kesehatan, Rineka Cipta, Jakarta.

Riduwan., 2009, Skala Pengukuran Variabel-Variabel Penelitian, Alfabeta, Bandung.

Rijadi, C., 2002, Faktor- faktor Yang Berhubungan Dengan Terjadinya Sisa Makanan Pasien Rawat Inap (Studi Kasus di Ruang Rawat Inap, Skripsi, FKM UNDIP, Semarang. 
Suryawati, C., Dharminto., Zahroh, S., 2006,Penyusunan Indikator Kepuasan Pasien Rawat Inap Rumah Sakit di Provinsi Jawa Tengah, Jurnal Manajemen Pelayanan Kesehatan, 09, 177-184.

Uyami., Hendriyani, H., Wijaningsih, W., 2012,Perbedaan Daya Terima, Sisa dan Asupan Makanan pada Pasien dengan Menu Pilihan dan Menu Standar di RSUD Sunan Kalijaga Demak, Jurnal Riset Gizi. 2 (1). 